\title{
IMPLEMENTASI KEWENANGAN PEMERINTAH DAERAH BERDASAR UNDANG-UNDANG NOMOR 22 TAHUN 1999
}

Oleh :

\author{
W. M. Heri Susilowati
}

\begin{abstract}
Regional authorities as autonomous regions in the framework of NKRI hased on ACt No. 22 year 1999 acquired by means of atribution, delegation and mandate, emphasized on accomplishment of decentralization principles by means of domestic arrangement system that is materially. formally and tangibly implemented. Practically the authority rest on factor of human resources supported by natural resources and availahility of sufficient equipment as well as organizations and management that have a satisfac* tory quality.
\end{abstract}

Keywords : Implementation, authority an regional governments

\section{PENDAHULUAN}

Milton J. Esman dalam bukunya "Managament Dimension of Development Per. spectives and Sirategies" tersebut menyatakan:

Di berbagai negara dunia ketiga pemerintahan daerah pada umumnya masih sangat tertinggal. Berbagai peraturan "modern" mengenai masalah bentuk ataupun proses pemerintahan tersebut cenderung tidak mempercayai para pemuka daerah yang kekuasaan politiknya didasarkan pada kekayaan ataupun pada kedudukan sosial tradisional, yang dikhawatirkan, akan terlepas dari kendali para pejabat pusat dan justru mendukung keinginan lawan politik mereka.

Dengan mengatasnamakan kepentingan kesatuan nasional, efisiensi pelaksanaan, serta modernisasi, para pejabat negara telah mengkonsentrasikan serta memusatkan tanggung jawab layanan masyarakat kepada para pejahat birokrat yang berada di bawahnya. Seringkali hal tersebut didorong oleh penguasa politik daerah yang kekuasaannya didasarkan pada pendekatan yang memungkinkan untuk mendapatkan dukungan pemerintah.

Demikian pandangan Milton tcrhadap keberadaan pemerintahan dacrah di negara-ncgara 
dunia ketiga. Pandangan tersebut didasari pada pola pikir ala barat yang rasional dan zakelijk yang sangat berlainan dengan pola pikir bangsa Indonesia yang masih mempercayai tahyul. Dengan demikian maka ukuran produktivitas di barat tidak sama dengan kita di Indonesia,

Perbedaan yang ada tersebut juga dipengaruhi adanya masalah-masalah sekitar latar belakang budaya, agama serta ras yang pada gilirannya menciptakan suatu budaya yang berciri sendiri yang sering disebut relligio magis cosmis. Oleh karena itu, tidak pada tempatnya untuk menyamakan ukuran produktivitas di negara maju dengan negara yang sedang berkembang seperti juga Indonesia.

Pada tataran saat ini yang sedang maraknya diterapkannya otonomi daerah berdasar UU No.22 Tahun 1999, maka tulisan Milton J. Esman dalam bukunya yang berjudul "Management Dimensions of Development Perspective and Strategies" dengan sub judul "Local Authorities" terdapat halhal yangmenarik untuk dibahas dan dikomentari lebih lanjut terutama menyangkut pemberian kewenangan kepada pemerintah daerah.

Adapun permasalahan yang akan dibahas adalah sebagai berikut :

1. Apakah yang menjadi dasar pemberian kewenangan kepada pemerintah daerah sebagai daerah otonom dalam kerangka Negara Kesatuan RJ dengan berdasar UU No.22 Tahun
1999?

2. Bagaimana kewenangan pemerintah daerah itu dijalankan oleh Badan atau Jabatan Administrasi Negara berdasarkan pada perolehan kewenangan tersebut?

3. Apakah yang menjadi kendala terhadap pelaksanaan kewenangan pemerintah daerah tersebut?

\section{PEMBAHASAN}

Negara Republik Indonesia sebagai Negara Kesatuan, di dalamnya terkandung prinsip bahwa Pemerintah Pusat berwenang ikut campur tangan secara lebih intensif terhadap persoalan-persoalan di daerah seperti yang tercantum dalam pasal 18 ayat (1) dan ayat (2) UUD 1945 yang setelah amandemen kedua, berbunyi:

\section{(Pasal 18 ayat (1) UUD 1945)}

"Negara Kesatuan Republik Indonesia dibagi atas daerah-dacrah provinsi dan daerah provinsi itu dibagi atas kabupaten dan kota, yang tiaptiap provinsi, kabupaten, dan kota itu mempunyai pemerintah daerah, yang diatur dengan undangundang."

(Pasal 18 ayat (2) UUD 1945)

"Pemerintah daerah provinsi, daerah kabupaten. dan kota mengatur dan mengurus sendiri urusan pemerintahan menurut asas otonomi dan tugas pembantuan."

Jika kehendak pembentuk negara Republik Indone. sia seperti yang tersebut dalam pasal 18 ayat (1) dan 
(2) UUD 1945 tersebut, dapatlah dikatakan bahwa Republik Indonesia adalah Negara Kesatuan yang di desentralisasikan. Pada dasarnya pembentuk UUD 1945 menghendaki adanya pembagian kewenangan antara pemerintah pusat dengan pemerintah daerah.

Sementara itu menurut UU No.22 Tahun 1999 tentang Pemerintahan Daerah, mengatur tentang kewenangan daerah pada Pasal 7-13 UU No.22 Tahun 1999. Pembagian kewenangan bidang pemerintahan antara pusat, daerah propinsi dan dacrah kabupaten/kota diatur dalam Pasal 7 - 11 UU No.22 Tahun 1999. Kewenangan pusat meliputi bidang-bidang yang tersebut dalam Pasal 7 yang menyatakan:

(Pasal 7 Ayat (1) UU No.22 Tahun 1999)

Kewenangan Daerah mencakup kewenangan dalam seluruh bidang pemerintahan, kecuali kewenangan dalam bidang politik luar negeri. pertahanan keamanan, peradilan, moneter dan fiskal, agama, serta kewenangan bidang lain. (Pasal 7 ayat (2) UUNo.22 Tahun 1999)

Kewenangan bidang lain, sebagaimana dimaksud pada ayat (1), meliputi kebijakan tentang perencanaan nasional dan pengendalian pembangunan nasional secara makro, dana perimbangan keuangan, sistem administrasi negara dan lembaga perekonomian negara, pembinaan dan pemberdayaan sumber daya manusia, pendayagunaan sumber daya alam serta teknologi tinggi yang strategis, konservasi, dan standarisasi nasional.

Pasal tersebut di atas sebagai suatu bukti dianutnya sistem rumah tangga materiil oleh UU No.22 Tahun 1999. Dengan demikian, semua kewenangan yang dapat dilaksanakan oleh Pemerintah Daerah adalah semua kewenangan bidang pemerintahan kecuali:

1. kewenangan dalam bidang politik luarnegeri;

2. kewenangan dalam bidang pertahanan keamanan;

3. kewenangan dalam bidang peradilan;

4. kewenangan dalam bidang moneter dan fiskal:

5. kewenangan dalam bidang agama;

6. kewenangan bidang lain yang meliputi:

- kebijakan tentang perencanaan nasional dan pengendalian pembengunan nasional secara makro:

- dana perimbangan keuangan;

- sistem administrasi negara dan lembaga perekonomian negara:

- pembinaan dan pemberdayaan sumber daya manusia;

- pendayagunaan sumber daya alam serta teknologi tinggi yang strategis:

- konservasi;

- dan standarisasi nasional.

Kemudian juga dapat dilihat dalam pasal 9 ayat (1) UU No.22 Tahun 1999, yaitu:

"Kewenangan provinsi sebagai Daerah Otonom mencakup kewenangan dalam bidang pemerintahan yang bersifat lintas kebupaten dan kota, serta kewenangan dalam bidang pemerintahar tertentu lainnya."

Dari Pasal 9 tersebut dapat dilihat 
kewenangan propinsi terdiri dari 2 (dua) kategori, yaitu kewenangan sebagai daerah otonom dan kewenangan sebagai wilayah administrasi. Kewenangan sebagai daerah otonom mencakup kewerangan dalam bidang pemerintahan yang bersifat lintas kabupaten dan kota, kewenangan dalam bidang pemerintahan tertentu lainnya, dan kewenangan yang tidak atau belum dapat dilaksanakan daerah kabupaten dan kota.

Selanjutnya juga terdapat dalam Pasal 10 ayat (1), (2), (3), dan (4) UU No.22 Tahun 1999. yang memberikan kewenangan kepada Daerah untuk mengelola sumber daya nasional yang tersedia di wilayahnya dan bertanggung jawab memelihara kelestarian lingkungan. Kewenangan Dacrah di wilayah laut meliputi

- eksplorasi, eksploitasi, konservasi, dan pengelolaan kekayaan laut sebatas wilayah tersebut;

- pengaturan kepentingan administratif;

- pengaturan tata ruang:

- penegakan hukum terhadap peraturan yang dikeluarkan olch Daerah atau yang dilimpahkan kewenangannya oleh Pemerintah; dan

- bantuan penegakan keamanan dan kadaulatan negara.

Sebagai peraturan pelaksanaan dari hal tersebut, telah dituangkan dalam PP No.25 Tahun 2000 tentang Kewerkangan Pemerintah dan Kewenangan Propinsi sebagai Daerah Otonom. Namun dalam PP No.25
Tahun 2000 tersebut menganut sistem rumah tangga formil, karena hampir tidnk ada perbedaan mendasar antara urusan yang dijalankan Pemerintah Pusat. Pemerintah Propinsi maupun Pemerintah Kota/ Kabupaten.

Menurut Pasal 4 PP No.25 Tahun 2000. kewenangan yang tidak atau belum dapat dilaksanakan oleh kabupaten/kota, ditentukan sebagai berikut:

1. Kabupaten/kota yang tidak atau belum mampu melaksanakan salah satu atau beberapa kewenangan dapat melaksanakan keweriangan tersebut melalui kerja sama antar kabupaten/kota, kerja sama antar kabupaten/kota dengan propinsi, atau menyerahkan kewenangan tersebut kepada propinsi.

2. Pelaksanaan kewenangan melalui kerjasuma atau penyerahan suatu kewenangan kepada propinsi harus didasarkan pada Keputusan Kepala Daerah Kabupaten/Kota dengan persetujuan Dewan Perwakilan Rakyat Dacrah (DPRD) Kabupaten/Kota.

3. Bupati/Walikota wajib menyampaikan keputusan mengenai penyerahan kewenangan kepada propinsi kepada Giubernur dan Presiden dengan tembusan kepada Dewan Pertimbangan Otonomi Daerah (DPOD).

4. Presiden setelah memperoleh masukan dari DPOD dapat menyetujui atau tidak menyetujui penyerahan kewenangan tersebut Dalam hal 
tidak menyetujui, kewenangan tersebut harus dilaksanakan oleh kabupaten/kota. Sementara jika menyetujui, pelaksanaan kewenangan tersebut diserahkan kepada propinsi.

5. Apabila dalam jangka waktu 1 (satu) bulan Presiden tidak memberikan tanggapan, maka penyerahan kewenangan tersebut dianggap disetujui:

6. Sebagai akibat penyerahan tersebut, propinsi sebagai dacrah otonom harus melaksanakan dengan pembiayaan yang dialokasikan dari dana perimbangan keuangan antara Pemerintah Pusat dan Daerah.

7. Apabila propinsi tidak mampu melaksanakan kewenangan tersebut, maka propinsi menyerahkannya kepada Pemerintah dengan mekanisme yang sama sebagaimana tercantum dalam angka 3 sampai angka 6.

8. Apabila kabupaten/kota sudah menyatakan kemampuannya menangani kewenangan tersebut, propinsi atau Pemerintah wajib mengembalikannya kepada kabupaten/kota tanpa persetujuan Presiden.

Kewenangan dalam bidang pemerintahan tertentu diatur dalam Pasal 3 ayat (2) PPNo.25 Tahun 2000 , meliputi perencanaan dan pengendalian pembangunan regional secara makro, pelatihan bidang tertentu, alokasi sumber daya manusia potensial, penelitian yang mencakup wilayah propinsi, pengelolaan pelabuhan regional, pengendalian lingkungan hidup. promosi dagang dan budaya pariwisata, penanganan penyakit menular dan hama tanaman, dan perencanaan tata ruang propinsi.

Sementara itu, kewenangan daerah kabupaten/kota mencakup seluruh kewenangan pemerintahan selain kewenangan pusat maupun daerah propinsi sebagaimana disebut di atas. Namun dalam Pasal 11 UU No.22 Tahun 1999, yang dinyatakan sebagai berikut:

(Pasal 11 ayat (1) UU No.22 Tahun 1999)

"Kewenangan Daerah Kabupaten dan Daerah Kota mencakup semua kewenangan pemerintahan selain kewenangan yang dikecualikan dalam Pasal 7 dan yang diatur dalam Pasal 9."

(Pasal 11 ayat (2) UU No.22 Tahun 1999)

"Bidang pemerintahan yang wajib dilaksanakan oleh Daerah Kabupaten dan Daerah Kota meliputi pekerjaan umum, kesehatan. pendidikan dan kebudayaan, pertanian, perhubungan, industri dan perdagangan, penanaman modal, lingkungan hidup, pertanahan, koperasi, dan tenaga kerja."

Kewenangan kabupaten/kota di wilayah laut adalah sejauh $1 / 3$ (sepertiga) dari batas laut daerah propinsi (lihat Pasal 10 UU No.22 Tahun I999).

Sementara itu sistem rumah tangga riil, dapat diketemukan dalam Pasal 5 ayat (1), Pasal 6 ayat (1), Pasal 6 ayat (2), dan 9 ayat (2) UUNo.22 Tahun 1999 yang berbunyi:

(Pasal 5 ayat (1) UUNo.22 Tahun 1999)

"Daerah dibentuk berdasarkan pertimbangan kemampuan ekonomi, potensi dacrah, sosial budaya, sosial politik, jumlah penduduk, luas daerah, dan pertimbangan lain yang 
memungkinkan terselenggaranya Otonomi Daerah."

(Pasal 6 ayat (1) UUNo.22 Tahun 1999)

"Kewenangan provinsi sebagai Daerah Otonom temasuk juga kewenangan yang tidak atau belum dapat dilaksanakan Daerah Kabupaten dan Daerah Kota."

(Pasal 6 ayat (3) UU No.22 tahun 1999)

"Kriteria tentang penghapusan, penggabungan. dan pemekaran daerah, sebagaimana dimaksud pada ayat (1) dan ayat (2), ditetapkan dengan Peraturan Pemerintah."

Pasal 9 ayat (2) UU No.22 Tahun 1999;

"Kewenangan provinsi sebagai Daerah Otonom termasuk juga kewenangan yang tidak atau belum dapat dilaksanakan Daerah Kabupaten dan Daerah Kota."

Kewenangan pemenintahan yang discrahkan kepada daerah dalam rangka desentralisasi harus disertai penyerahan dan pengalihan pembiayaan. sarana dan prasarana, serta sumber daya manusia.

Adapun kewenangan Pemerintah dan Propinsi sebagai daerah otonom menurut PP No.25 Tahun 1999 dapat diuraikan dalam tabel berikut:

Sementara kewenangan pemerintahan yang dilimpahkan kepada Gubernur dalam dekonsentrasi hanus disertai dengan pembiayaan (Pasal 8 UU No.22 Tahun 1999). Pemerintah juga dapat menugaskan kepada daerah urusan-urusan pemerintahan tertentu dalam rangka tugas pembantuan, yang disertai pembiayaan, sarana dan prasarana, serta sumber daya manusia. Penugasan tersebut dibebani kewajiban melaporkan pelaksanaannya dan pertanggungjawabannya kepada Pemerintah (Pasal
13 UU No.22 Tahun 1999)

Pembagian kewenangan pemerintahan terhadap Badan ataupun Jabatan adminstrasi negara untuk melaksanakan pemerintahan tersebut, dapat dilakukan dengan jalan atribusi dan delegasi dan juga mandat. Menurut Kamus Istilah Hukum-Fockema Adreae Belanda Indonesia, kata atribusi (Belanda Attributie) mengandung arti:

Pembagian (kekuasaan); dalam kata attributie van rechtsmacht: pembagian kekuasaan kepada berbagai instansi (absolute competentie) kompetensi mutlak), sehagai lawan dari distributie van rechtsmacht. Juga: membagikan suatu perkara kepada kekuasaan yudikatif atau kekuasaan eksekutif. Coflicten van attributic, konflik permbagian kekuasaan. (Kamus Istilah Hukum-Fockema Adreae Belanda Indonesia. 1983:36 dalam Markus Lukman, 1997: 118)

Sedangkan kata delegasi (Belanda = Delegatie) mengandung arti:

Penyerahan wewenang dari pejabat yang Iebih tinggi kepada yang lebih rendah: penyerahan yang demikian dianggap tidak dapat dibenarkan selain dengan atau berdasarkan kekuatan hukum. Misal; Dewan Perwakilan Daerah Kotapraja memerintahkan kepada majelis walikota dan pembantu walikota untuk mengaklakan peraturanperaturan tertentu. (Kamus Istilah HukumFockema Adreae Belanda Indonesia, 1983:91 dan 286 dalam Markus Lukman, 1997: 118) 
PERSPEKTIF Volume LX No.1 Tahun 2004 Edisi Jamuari

\section{Kewenangan Pusat, Propinsi, Kabupaten/Kota}

Berdasarkan PP No. 5 Tahun 2000

\begin{tabular}{|c|c|c|}
\hline KEWENANGAN PUSAT & KEWENANGAN PROPINSI & $\begin{array}{c}\text { KEWENANGAN } \\
\text { KABUPATEN/KOTA }\end{array}$ \\
\hline $\begin{array}{l}\text { Mencakup bidang politik luar } \\
\text { negeri, pertahanan dan } \\
\text { keamanan, peradilan, moneter } \\
\text { dan fiskal, agama serta } \\
\text { kewenangan bidang lain. }\end{array}$ & $\begin{array}{l}\text { Mencakup kewenangan dalam } \\
\text { bidang pemerintah yang } \\
\text { bersifat lintas kabupaten/kota, } \\
\text { kewenangan dalam bidang } \\
\text { pemerintah tertentu lainnya, dan } \\
\text { kewenangan yang tidak atau } \\
\text { belum dapat dilaksanakan oleh } \\
\text { kabupaten/kota. }\end{array}$ & $\begin{array}{l}\text { Mencakup seluruh kewenangan } \\
\text { pemerintahan selain } \\
\text { kewenangan Pusat maupun } \\
\text { Daerah Propinsi. }\end{array}$ \\
\hline $\begin{array}{l}\text { Kewenangan bidang lain } \\
\text { tersebut dikelompokkan ke } \\
\text { dalam } 25 \text { bidang, yaitu } \\
\text { pertanian, kelautan, } \\
\text { pertambangan dan energi, } \\
\text { perindustrian dan perdagangan, } \\
\text { perkoperasian, penanaman } \\
\text { modal, kepariwisataan, } \\
\text { ketenagakerjaan, kesehatan, } \\
\text { pendidikan dan kebudayaan. } \\
\text { Sosial, penataan ruang, } \\
\text { pertahanan, pemukiman, } \\
\text { pekerjaan umum, perhubungan, } \\
\text { Lingkungan hidup, politik } \\
\text { dalam negeri dan administrasi } \\
\text { publik pengembangan otonomi } \\
\text { daerah perimbangan, keuangan, } \\
\text { kependudukan, olah raga, } \\
\text { hakim, dan perundang- } \\
\text { undangan, penerangan. }\end{array}$ & $\begin{array}{l}\text { Kewenangan dalam bidang } \\
\text { pemerintahan tertentu lainnya } \\
\text { dikelompokkan ke dalam } 20 \\
\text { bidang, yaitu pertanian, } \\
\text { kelautanan, pertambangan dan } \\
\text { energi, kehutanan dan } \\
\text { perkebunan, perindustrian, dan } \\
\text { perdagangan, perkoperasian, } \\
\text { penanaman modal, } \\
\text { ketenagakerjaan, kesehatan } \\
\text { pendidikan dan kebudayaan } \\
\text { sosial. penataan ruang } \\
\text { pemukiman, pekerjaan umum, } \\
\text { perhubungan, lingkungan hidup, } \\
\text { politik dalam negeri dan } \\
\text { administrasi publik, } \\
\text { pengembangan otonomi daerah, } \\
\text { perimbangan dan perundang. } \\
\text { undangkan. }\end{array}$ & $\begin{array}{l}\text { Meskipun demikian, ada } \\
\text { beberapa kewenangan yang } \\
\text { wajib dilaksanakan, } \\
\text { sebagaimana diatur dalam pasal } \\
11 \text { ayat (2)UU No. } 22 \text { tahun } \\
1999 \text {. }\end{array}$ \\
\hline
\end{tabular}

Berikutnya kata mandat (Belanda = Mandaat) mengandung art:

Mandaat, pada umumnya: Opdracht, perintah; Imperatief mandaat. Di dalam pergaulan hukum, baik pemberian kuasa (lastgeving), maupun kuasa penuh (volmacht).

Mandaat van beschikkings bevoegheid, mandat mengenai kewenangan penguasa, yang diartikan dengan pemberian kuasa (biasanyabersamaan dengan perintah) oleh alat perlengkapan pemerintah yang memberi wewenang ini kepada yang lain yang akan melaksanakannya atas nama tanggung jawab alat pemerintah yang pertama tersebut. 
Pada atribusi/attributie (pembagian kekuasaan hukum) diciptakan suatu wewenang, pada delegasi (delegatie) diserahkan suatu wewenang, pada mandat tidak ada penciptaan ataupun penyerahan wewenang. Ciri pokok mandat adalah suatu bentuk perwakilan, Mandataris berbuat atas nama yang diwakili. (Garis bawah oleh penulis). (Kamus Istilah Hukum-Fockema Adreae Belanda Indonesia, 1983:286 dalam Markus Lukman, 1997: 119)

Dari uraian di atas dapat dikatakan pada dasarnya atribusi terjadi pemberian kewenangan pemerintahan yang baru oleh suatu ketentuan dalam peraturan perundang-undangan. Dalam hal ini dilahirkan suatu kewenangan pemerintahan baru. Legislator yang kompeten untuk memberikan atribusi wewenang pemerintahan itu dibedakan antara:

a. Yang berkedudukan sebagai original legislator: di negara kita di tingkat pusat adalah MPR sebagai pembentuk konstitusi dan DPR bersama dengan Presiden sebagai pembentuk UU dan Presiden karena berwenang untuk membentuk Peraturan Pemerintah Pengganti Undang-undang. Sedangkan di tingkat daerah adalah DPRD dan Pemerintah Daerah yang membetuk Peraturan Daerah.

b. Yang bertindak sebagai delegated legislator: seperti Presiden yang berdasar pada suatu ketentuan UU mengeluarkan suatu Peraturan Pemerintah di mana diciptakan wewenang pemerintahan kepada Badan atau Jabatan Tata Usaha Negara tersebut. (Indroharto, 1994:91). Sedang pada delegasi terjadilah pelimpahan suatu wewenang yang telah ada oleh Badan atau Jabatan Tata Usaha Negara yang telah memperoleh suatu wewenang pemerintahan secara atributifkepada Badan atau Jabatan Tata Usaha Negara lainnya. Dengan demikian suatu delegasi selalu didahului oleh adanya suatuatribusi wewenang.

Pada atribusi wewenang, terjadi pemberian suatu wewenang oleh suatu ketentuan peraturan perundang-undangan, sedang pada delegasi di situ terjadi pelimpahan atau pemindahan suatu wewenang yang telah ada, sehingga selama pendelegasian itu berlangsung, pemberi delegasi akan kehilangan wewenang yang telah didelegasikan. Bila delegasi ingin menarik kembali wewenang yang telah didelegasikan, maka harus dengan peraturan perundang-undangan yang sama. Kemudian wewenang yang diperoleh dari delegasi itu dapat pula disubdelegasikan kepada sub delegataris. Untuk sub delegasi ini berlaku sama seperti delegasi.

Pada mandat, di situ tidak terjadi suatu pemberian wewenang baru maupun pelimpahan wewenang. Dalam hal mandat, maka di situ tidak terjadi perubahan apa-apa mengenai distribusi wewenang yang telah ada, yang ada hanya suatu hubungan intern. Wewenang dilaksanakan oleh mandataris atas nama dan tanggung jawab mandans (pihak yang memberikan mandat). Kemudian 
wewenang yang diperoleh dari atribusi maupun delegasi dapat dimandatkan kepada organ atau pejabat bawahannya bilamana organ atau pejabat yang secara resmi memperoleh wewenang itu tetapi tidak mampu melaksanakan sendiri wewenang tersebut. Hanya saja pada mandat, mandans tetap berwenang untuk menangani sendiri wewenangnya bila ia menginginkannya. Mandans juga dapat memberi petunjuk kepada mandataris yang dianggap perlu. Mandans bertanggung jawab sepenuhnya atas keputusan yang diambil berdasarkan mandat. Sehingga yuridis formal mandataris bukan orang lain dari mandans.

Perlu pula dikemukakan pendapat Hene van Maarseveen dan H.G. Lubberdink yang dikutip oleh Soewito sebagai berikut:

Maarseveen tidak membedakan "pelimpahan tugas" dengan "pelimpahan wewenang". Namun diakui bahwa pelimpahan dalam bentuk delegatie, delegataris bertindak atas nama sendiri dan atas beban tanggung jawab. Dengan begitu delegataris dapat diminta pertanggungjawaban dan dapat pula digugat karena kesalahannya menjalankan kekuasaan yang diperolehnya. Seorang mandataris bertindak atas nama pemberi kuasa ("mandat") dan tidak memiliki wewenang penuh dalam menjalankan kekuasaannya.

Menurut Lubberdink pertanggungjawaban untuk pelaksanaan wewenang tetap pada pemberi kuasa, sebab pemberi kuasa yang memberikan petunjuk baik yang umum maupun petunjuk yang khusus kepada mandataris. (Soewoto, 1987:7)

Berbagai kemungkinan suatu badan atau pejabat administrasi negara memperoleh wewenangnya melalui atribusi, delegasi, dan mandat, digambarkan oleh B. de Goede sebagai berikut: (B. de Goede, 1986:56)

Pada kewenangan yang dimiliki oleh para pejabat administrasi Pemerintah Daerah Otonom itu merupakan kewenangan yang diperoleh melalui jalan atribut kewenangan.

Sementara itu kewenangan sebagai wilayah administrasi mencakup kewenangan dalam bidang pemerintahan yang dilimpahkan kepada Gubernur selaku wakil Pemerintah Pusat di daerah. Kewenangan tersebut diperoleh dengan jalan delegasi kewenangan dan pejabat yang melaksanakannya yakni Gubernur adalah sebagai delegataris.

Kemudian untuk kewenangan tugas pembantuan yang merupakan kewenangan pemerintah pusat yang kemudian dimandatkan kepada orang-orangnya untuk melaksanakan urusan tersebut.

Menurut pendapat Milton J. Esman bahwa masih perlu adanya sentralisasi terhadap beberapa urusan yang dilaksanakan oleh pusat, penulis sependapat tentang hal itu; yakni bahwa sentralisasi hanya untuk hal-hal tertentu yang dipandang atau diduga daerah memang tidak akan mampu melaksanakannya dengan mengingat kondisi dan 
situasi daerah yang bersangkutan serta sifat urusannya yang memang sangat memerlukan keseragaman dalam penanganannya. Kemudian permasalahan yang muncul adalah bahwa pelaksanaannya seringkali dapat mematikan aspirasi yang ada di daerah untuk turut serta berpartisipasi dalam penyelenggaraan pemerintahan khususnya di daerahnya.

Dalam tulisannya, Milton J. Esman juga menyoroti adanya kecenderungan ketidak-percayaan pemerintah pusat kepada pemerintah daerah dan juga adanya konsep sentralisasi hanya untuk hal-hal tertentu serta berdasarkan pada sifat dan kondisi daerah yang pada gilirannya akan menimbulkan apatisme dan curiga mencurigai antara pusat dan daerah. Hal itu menurut penulis tidak sepenuhnya benar, karena semua berpulang kepada daerah untuk mengembangkan daerahnya sendiri berdasar kemampuannya, akan sangat tergantung pada partisipasi masyarakat daerah tersebut.

Berdasar pengalaman, dalam pelaksanaan bidang-bidang tugas tertentu sistem sentralisasi tidak dapat menjamin kesesuaian tindakan-tindakan pemerintahan dengan keadaan-keadaan khusus di daerah. Maka untuk mengatasi hal ini, paling sedikit sistem sentralisasi itu harus diperlunak, yaitu dengan melaksanakan sistem dekonsentrasi teritotial, dalam mana kepada organ-organ Pemerintah Pusat di daerah-daerah diberikan kekuasaan untuk melaksanakan kebijaksanaan Pemerintah sesuai dengan keadaan khusus di daerah-daerah masing- masing. Namun sistem inipun belum dapat menjamin efektivitas dan efisiensi pemerintahan, sebab pemerintah setempat masih tetap terikat oleh instruksiinstruksi Pemerintah Pusat dan tidak mempunyai kebebasan yang cukup luas dalam menyelenggarakan kepentingan masyarakat daerah; oleh karena itu digunakan sistem desentralisasi teritorial.

Sistem desentralisasi, umumnya menyangkut 2 (dua) hal yaitu teritorial (politik) dan fungsional. Menurut Bayu Suryaningrat, desentralisasi adalah:

Mewujudkan asas desentraliasi dalam pemerintahan negara dalam desentralisasi ini rakyat secara langsung mempunyai kesempatan untuk turut serta (participation) dalam penyelenggaraan pemerintahan di daerahnya.

Desentralisasi kenegaraan dapat dibedakan antara:

1. Desentralisasi teritorial (territoriale decentralisatir), yang penyerahan kekuasaan untuk mengatur dan mengurus numah tangganya sendiri (autonomie), batas pengaturan termaksud adalah daerah:

2. Desentralisasi fungsional (functionale decentralisatie) yaitu pelimpahan kekuasaan untuk mengatur dan mengurus fungsi tertentu. Batas pengaturan tersebut adalah jenis fungsi misalnya pendidikan, pengairan dan sebagainya. (Bayu Suryaningrat, 1981:6-7)

Amrah Muslimin mengemukakan ada 3 (tiga) 
macam desentralisasi yaitu:

desentralisasi politik, pengakuan adanya hak mengurus kepentingan rumah tangga sendiri pada badan-badan politik di daerah-daerah yang dipilih oleh rakyat dalam daerah-daerah tertentu, desentralisasi fungsional sebagai pengakuan adanya hak pada golongan-golongan mengurus satu macam atau golongan kepentingan dalam masyarakat, baik serikat atau tidak pada suau daerah tertentu. Umpama Subak di Bali; dan desentralisasi kebudayaan, yang mangakui adanya hak pada golongan kecil, masyarakat menyelenggarakan kebudayaannya sendiri (mengatur pendidikan, agama dan lain-lain. (Amrah Muslimin, 1960:89).

Sementara itu setelah berlakunya UU No.22 Tahun 1999 tentang Pemerintahan Daerah, sebagai pengganti dari UU No.5 Tahun 1974 dan UU No.5 Tahun 1979, memberikan pengertian desentralisasi dalam pasal 1(e) sebagai berikut:

"Penyerahan wewenang pemerintahan oleh Pemerintah kepada Daerah Otonom dalam kerangka Negara Kesatuan Republik Indonesia." Menurut The Liang Gie, alasan dianutnya desentralisasi adalah:

1. dilihat dari sudut politik sebagai permainan kekuasaan, desentralisasi dimaksudkan untuk mencegah penumpukan kekuasaan pada satu pihak saja yang pada akhirnya dapat menimbulkan tirani;
2. Dalam bidang politik penyelenggaraan desentralisasi dianggap sebagai tindakan pendemokrasian, untuk menarik rakyat ikut serta dalam pemerintahan dan melatih diri dalam mempergunakan hak-hak demokrasi;

3. Dari sudut teknik organisatoris pemerintah, alasan mengadakan pemerintahan daerah (desentralisasi) adalah semata-mata untuk mencapai suatu pemerintahan yang efisien. Apa yang dianggap lebih utama untuk diurus oleh pemerintah setempat pengurusnya diserahkan kepada daerah. Hal-hal yang lebih tepat di tangan Pusat tetap diurus oleh Pemerintah Pusat;

4. Dari sudut kultural, desentralisasi perlu diadakan supaya perhatian dapat sepenuhnya ditumpahkan kepada kekhususan sesuatu daerah, sepertigeografi, keadaan penduduk, kegiatan ekonomi, watak kebudayaan atau latar belakang sejarahnya;

5. Dari sudut kepentingan pembangunan ekonomi, desentralisasi diperlukan karena pemerintah daerah dapat lebih banyak dan secara langsung membantu pembangunan tersebut. (The Liang Gie, 1968: 37-38, 4041).

Dalam pelaksanaan desentralisasi teritorial atau dengan istilah yang biasa digunakan adalah hak otonomi (pemerintahan sendiri), dalam prakteknya 
tidak semua tugas pemerintahan itu diserahkan kepada masyarakat atau Pemerintah Daerah. Ternyata masih ada tugas-tugas pemerintahan yang tetap dilakukan oleh Pemerintah Pusat, sebabnya ialah:

pertama, ada tugas-tugas yang penyelenggaraannya lebih efektifkalau dilakukan secara sentral, dan

kedua, masyarakat setempat dianggap belum cukup mampu untuk mengurus tugas-tugas tertentu misalnya karena dalam masyarakat yang bersangkutan belum tersedia tenaga-tenaga kapabel, dan belum ada sumber-sumber keuangan yang cukup. (Josef Riwu Kaho, 1991:10).

Dari sebab itu, kita tidak boleh melupakan bahwa pada akhimya isi otonomi (yaitu kuantitas/ banyaknya tugas-tugas atau urusan-urusan yang diselenggarakan sendiri oleh Daerah) itu tergantung kepada tingkat perkembangan serta kemampuan masyarakat Daerah sendiri.

Berdasar hal tersebut di atas, maka sistem dekonsentrasi dan desentralisasi itu dapat digunakan secara bersama-sama dalam imbangan yang sesuai dengan tingkat perkembangan dan kemampuan masyarakat daerah dan sebenamya tergantung pada soal, apakah suatu tugas itu lebih efektif penyelenggaraannya kalau digunakan sistem dekonsentrasi atau bahkan sentralisasi. Walaupun di daerah berlaku desentralisasi, tetapi normanya tetap sentralistik; karena tidak ada desentralisasi yang mumi dalam pelaksanaannya.

Di samping asas-asas Pemerintahan Daerah tersebut di atas, juga dilaksanakan sistem rumah tangga daerah yang dapat dibagi dalam:

1. sistem numah tangga materiil

2. sistem numah tangga formil

3. sistem numah tangga riil

4. sistem rumah tangga residu.

Pada sistem rumah tangga materiil, pemberian kewenangan kepada di daerah dengan didasari suatu pertimbangan dan keyakinan bahwa daerah akan mampu melaksanakan urusan yang di serahkan kepadanya. Dalam pengertian sistem otonomi materiil ini antara Pemerintah Pusat dan Pemerintah Daerah ada pembagian tugas (wewenang dan tanggung jawab) yang eksplisit (diperinci secara tegas) dalam undang-undang pembentukannya. Artinya, otonomi daerah itu hanya meliputi tugas-tugas yang telah ditentukan satu per satu, jadi bersifat definif. Di sini yang berbeda adalah materi yang menjadi objek pengurusan dan pengaturan dari masyarakat dacrah itu sendiri.

Sementara itu, untuk sistem rumah tangga formil, melihat bahwa pada dasarnya Pemerintah Dacrah mempunyai kemampuan yang sama dengan Pemerintah Pusat dalam melaksanakan kewenangan yang diberikannya; dengan lebih mengutamakan pada aspek efisiensi penyelenggaraan tugas pelayanan publik. Dalam pengertian ini, tidak ada perbedaan 
sifat antara urusan-urusan yang diselenggarakan oleh Pemerintah Pusat dan oleh daerah-daerah otonom. Bila ada pembagian tugas (wewenang dan tanggung jawab), hal ini hanya semata-mata disebabkan pertimbangan-pertimbangan yang rasional dan praktis. Artinya, pembagian tugas itu tidaklah disebabkan materi yang diatur berbeda sifatnya, tetapi adanya keyakinan bahwa kepentingan daerah tersebut dapat lebih baik dan berhasil (lebih efisien) apabila diselenggarakan sendiri oleh daerah masing-masing dari pada oleh Pemerintah Pusat. Tugas dari daerah otonom secara normatif tidak terperinci di dalam undang-undang pembentukannya, tetapi ditentukan dalam suaturumusan yang umum saja Rumusan umum itu hanya mengandung asas-asas saja, sedangkan pengaturan lebih lanjut diserahkan kepada Pemerintah Daerah. Batasannya tidak ditentukan secara pasti, tetapi bergantung dari keadaan, waktu dan tempat. Dengan demikian hasil guna dan daya guna sistem ini sangat tergantung pada kreativitas dan aktivitas daerah otonom.

Sistem rumah tangga riil, penyerahan urusan atau tugas dan kewenangan kepada daerah didasarkan pada faktor yang nyata atau riil, sesuai dengan kebutuhan dan kemampuan yang riil dari daerah maupun Pemerintah Pusat maupun pertumbuhan masyarakat yang terjadi. Dengan demikian lebih menonjolkan pada kemampuan nyata yang dimiliki oleh daerah dalam melaksanakan urusan yang menjadi kewenangannya maupun kewenangan yang tidak atau belum dapat dilaksanakan daerah yang ada di bawahnya. Oleh karena pemberian tugas dan kewajiban serta wewenang ini didasarkan pada keadaan yang nyata di dalam masyarakat, membawa konsekuensi bahwa tugas dan urusan yang selama ini menjadi wewenang Pemerintah Pusat dapat diserahkan kepada Pemerintah Daerah, dengan mempertimbangkan kemampuan masyarakat daerah untuk mengatur dan mengurusnya sendiri. Sebaliknya, tugas yang telah menjadi wewenang daerah pada suatu ketika, bilamana dipandang perlu, dapat ditarik kembali oleh Pemerintah Pusat. Sistem rumah tangga riil ini merupakan penggabungan dari sistem rumah tangga materiil dan sistem rumah tangga formil.

Kemudian untuk hal-hal yang tidak termasuk dalam ketiga sistem rumah tangga tersebut adalah sistem rumah tangga residu (sisa). Dalam sistem ini secara umum telah ditentukan terlebih dahulu tugastugas yang telahmenjadi wewenang Pemerintah Pusat, sedangkan sisanya menjadi urusan rumah tangga daerah. Kebaikan dari sistem ini terletak pada saat timbulnya keperluan-keperluan baru, Pemerintah Daerah dapat dengan cepat mengambil keputusan dan tindakan yang dipandang perlu, tanpa menunggu perintah dari pemerintah pusat. (Kaho, 1997:15). Jadi dalam sistem rumah tangga ini terdapat kewenangan yang belum dilaksanakan olch Pemerintah Pusat dan tidak diberikannya kewenangan kepada daerah, namun karena daerah merasa perlu dan mampu melaksanakannya, maka hal tersebut akan 
dapat dilaksanakan oleh Pemerintah Daerah tersebut tanpa menunggu perintah dari pemerintah pusat.

Lislie Lipson dalam bukunya "The Great Issues of Politics: An Introduction to Political Science" (1981:15), menjabarkan 5 (lima) masalah besar (great issues), yaitu:

1. The coverage of citizenship: Should it be exclusive or all inclusive?

2. The functions of the state: Should its shere of activity be limited or unlimited?

3. The source of authirity: Should it originate in the people or government?

4. The structure of authorithy: Should power be concentrated or dispered?

5. The magnitude of the state and its external relations: What unit of government is preferable? What interstate order is desirable?

Dalam kaitan dengan hal tersebut di atas, lebih lanjut Lipson menegaskan:

The first isstue is the choise between equality and inequality.

The second issue is the choise between a pluralist and monistic state.

The third issue is the choise between freedom and dictatorship.

The fourth issue is the choice between a dispersion of power and their unification.

The fifth issue is the choice between a multitude of state and a universal state (Lislie
Lipson, 1981:16).

Dari kelima masalah besar tersebut, masalah keempat berkaitan langsung dengan masalah pilihan antara centralization dan local autonomy. Bila pilihan jatuh pada local autonomy, berarti Pemerintah Pusat harus menyelenggarakan desentralisasi atau dengan perkataan lain, penyelenggaraan desentralisasi merupakan konsekuensi dari pemilihan yang dijatuhkan pada local autonomy. (Josef Riwu Kaho, 1991:2).

Berdasarkan pada teori desentralisasi seperti dikemukakan oleh Bulthuis, bahwa:

Desentralisasi adalah suatukeadaan yang terjadi apabila:

1. Kewenangan untuk mengambil keputusan diserahkan dari seseorang pejabat administrasi / pemerintah kepada yang lain;

2. Pejabat yang menyerahkan itu mempunyai lingkungan pekerjaan yang lebih luas daripada pejabat yang diserahi kewenangan tersebut;

3. Pejabat yang menyerahkan kewenangan tidak dapat memberi perintah kepada pejabat yang telah diserahi kewenangan itu mengenai pengambilan / pembuatan keputusan atau isi keputusan itu;

4a. Pejabat yang menyerahkan kewenangan itu tidak dapat menjadikan keputusannya sendiri sebagai pengganti keputusan yang telah diambil/dibuat; 
4b. Pejabat yang menyerahkan kewenangan itu tidak dapat secara bebas menurut pilihan sendiri sebagai pengganti keputusan yang telah diserahi kewenangan itu dengan orang lain;

5. Pejabat yang menyerahkan kewenangan itu tidak dapat menyingkirkan pejabat yang telah diserahi kewenangan itu dari tempatnya.

Pendapat di atas merupakan pemahaman dari sistem desentralisasi murni, nampak bahwa penyerahan kewenangan kepada daerah oleh Pemerintah Pusat atau pemerintah yang ada di atasnya, membawa konsekuensi bahwa adanya hak otonomi yang dari daerah-daerah berarti pembatasan terhadap kekuasaan yang dimiliki oleh Pemerintah Pusat; baik mengenai penyelenggaraan urusan-urusan tertentumaupun pengaturannya. Selanjutnyamengenai kekuasaan otonomi dalam tiap-tiap lapangan pekerjaan adalah tergantung dari sejarah pembentukan masing-masing negara, apakah otonomi diberikan dari atas (Pemerintah Pusat) ataukah otonomi itu berkembang dari bawah dan oleh Pemerintah Pusat atas dasar permusyaratan kemudian diberi dasar formil yuridis. Dengan demikian akan nampak bahwa otonomi merupakan realisasi dari pengakuan, bahwa kepentingan dan kehendak rakyat merupakan satu-satunya sumber untuk menentukan sistem dan jalannya pemerintahan negara atau dengan perkataan lain, otonomi daerah adalah bagian keseluruhan dari usaha mewujudkan kedaulatan rakyat dalam pemerintahan. Menurut Mariun dalam bukunya "Azas-azas Ilmu Pemerintahan" bahwa alasan bagi dianutnya desentralisasi adalah:

1. demi tercapainya efektivitas pemerintahan;

2. demi terlaksananya demokrasi di/dari bawah (grassroots democracy).

Di negara-negara dunia ketiga pada umumnya, kewenangan yang dimilikinya sebagai pemberian dari pemerintah yang ada di atasnya - pada kenyataannya seringkali mengalami kesulitankesulitan, dalam hal ini dapat dikatakan tidak ada negara demokrasi yang menolak pemberian hak otonomi kepada daerah-daerahnya. Kesulitan ini antara lain berkaitan dengan bagaimana pengaturan pembagian wewenang antara Pusat dan Daerah, sedang di lain pihak bagaimana agar Pemerintah Pusat selaku pemegang kekuasaan tunggal dalam Negara Kesatuan, tetap dapat terjamin. Mengingat juga perkembangan peranan Pemerintah Pusat yang makin bertambah penting, di mana hampir tidak ada lagi bidang kehidupan yang terlepas dari campur tangan/ pengaruh Pemerintah Pusat, maka ada kemungkinan sesuatu masalah yang sebelumnya adalah hanya bersifat lokal berubah menjadi persoalan penting yang menyangkut Negara dan bangsa keseluruhan. J.P. Oud, pakar bestuurkunde dari Belanda menegaskan bahwa otonomi bukan hanya wewenang untuk mengatur dan mengurus urusan sendiri, tetapi mencakup penggunaan wewenang itu secara mandiri, hanya tetap di bawah pengawasan wewenang itu 
secara mandiri, hanya tetap di bawah pengawasan Pemerintah Pusat. Alasan-alasan pemerintah pusat untuk melakukan pengawasan terhadap daerah dapat dikaitkan dengan hal-hal sebagai berikut:

(a). To maintain minimum standards in the performance of service by local authorities:

(b). To maintain of standart of administrationas well as coordinateadministration between and among various levels of government;

(c). To protect the citizens against the abuse of powers by local authorities.

(d). To control local expenditures as part of the management and planning of the national economy;

(e). To wield and integrate the diverse people into a nation.

Sebagai akibatnya, maka Pemerintah harus menetapkan dan menjaga atau mempertahankan standart minimum dalam pemberian pelayanan kepada masyarakat yang dilakukan oleh Pemerintah Daerah. Dengan demikian, kualitas atau mutu pelayanan akan tetap terpelihara dengan baik. Demikian juga halnya dengan standart minimum administrasi harus ditetapkan agar keseragaman dan kontinuitas dapat terjamin. Sebab itu, maka penentuan standart secara nasional akan dapat terjamin. Sebab itu, maka penentuan standart secara nasional akan dapat membantu mendorong adanya perlakuan yang sama tehadap rakyat di Daerah yang memerlukan pelayanan dari Pemerintah Daerah, seperti halnya dengan pelayanan yang diberikan oleh Pemerintah Pusat kepada masyarakat secara umum. Pengawasan yang dilakukan oleh Pemerintah Pusat dapat menghasilkan koordinasi antara pelbagai tingkatan pemerintahan, khususnya antara pejabat-pejabat Daerah yang jelas berbeda-beda antara satu dengan lainnya.

Selanjutnya yang menjadi ukuran kemandirian daerah otonom adalah:

1. Jumlah wewenang atau urusan pangkal;

2. Jumlah urusan pemerintahan yang riil yang dimiliki oleh Daerah;

3. Jumlah fungsi dalam suatu urusan pemerintahan yang dimilikinya;

4. Jumlah Peraturan Daeah rata-rata tiap tahun dalam tempo lima tahun;

5. Jumlah Dinas atau Badan/Lembaga milik Daerah;

6. Jumlah PAD dalam perbandingan proporsion dengan jumlah urusan dan wewenangnya;

7. Jumlah PAD dibanding dari pemerintah "atasan" (Pemerintah Pusat dan Pemerintah Daerah Tingkat I) (Ateng Syafrudin, 1994:2) Tingkat kemandirian Daerah sebagaimana tersebut di atas masih harus dinilai juga dari aspek-aspek lain tentang keberhasilan melaksanakan fungsi-fungsi membangun manusia seutuhnya dan masyarakat secara keseluruhan yang mengandung unsur keadilan 
dalam kesejahteraannya.

Dalam menentukan pemberian ataupun penarikan kembali otonomi kepada daerah, maka dibentuk Dewan Pertimbangan Otonomi Daerah (DPOD) berdasar Keppres No.23 Tahun 1975 yang susunan keanggotaan DPOD terdiri dari:

1. Menteri Dalam Negeri sebagai Ketua merangkap anggota

2. Menteri Negara Ekuin sebagai anggota

3. Menteri Negara Ketua BAPPENAS sebagai anggota

4. Menteri Negara Penertiban Aparatur Negara sebagai anggota

5. Menteri Pertahanan Keamanan sebagai anggota

6. Menteri Keuangan sebagai anggota

7. Menteri Kesejahteraan Rakyat sebagai anggota

Kemudian ditambah Dirjen PUOD sebagai

Sekretaris/bukan anggota

Dewan Pertimbangan Otonomi Daerah mempunyai tugas merumuskan pertimbangan:

1. Pembentukan Daerah Otonom

2. Penambahan/perluasan Daerah Otonom

3. Penghapusan Daerah Otonom

4. Penarikan kembali urusan otonomi

5. Penambahan sumber keuangan Daerah

6. Perubahan struktur perimbangan keuangan.

Dari uraian tersebut dapat ditampilkan adanya beberapa faktor-faktor yang mempengaruhi pelaksanaan otonomi antara lain adalah:

1. Faktor manusia pelaksana yakni pejabat-pejabat di Daerah, kemampuan Aparatur Pemerintahan Daerah dan partisipasi Masyarakat;

2. Faktor keuangan daerah yakni pajak daerah, retribusi daerah, perusahaan daerah dan Dinas Daerah dan pendapatan lainnya;

3. Faktor peralatan;

4. Faktor organisasi dan manajemen.

\section{PENUTUP}

1. Dasar dari pemberian kewenangan kepada pemerintah daerah sebagai daerah otonom dalam kerangka Negara Kesatuan Republik Indonesia dengan berdasar UUNo.22 Tahun 1999 adalah kemampuan daerah yang digali dengan berdasar pada pemberian otonomi dengan menitik beratkan pada pelaksanaan asas desentralisasi dengan sistem rumah tangga yang dijalankan secara materiil, formil dan nyata.

2. Kewenangan pemerintah daerah itu dijalankan oleh Badan atau Jabatan Administrasi Negara berdasarkan pada perolehan kewenangan dengan jalan atribusi, delegasi dan mandat.

3. Kendala dalam pelaksanaan kewenangankewenangan pemerintah dacrah tersebut bertumpu pada faktor sumber daya manusianya dalam mengelola pelaksanaan kewenangan tersebut, kemudian juga didukung oleh sumber daya alam yang memadai yang sangat terkait dengan sumber pendanaan bagi terlaksananya kewenangan tersebut. Di samping itu juga faktor 
tersedianya peralatan yang memadai dan organisasi dan manajemen yang berkualitas.

\section{DAFTAR PUSTAKA}

Abdurrahman, ed., Beberapa Pemikiran Tentang Otonomi Dacrah, PT. Media Sarana Press, Jakarta, 1987.

Amrah Muslimin, Ikhtisar Perkembangan Otonomi Daerah 1903-1958, Jambatan, Jakarta, 1960.

Ateng Syafrudin, Titik Berat Otonomi Daerah Pada Daerah Tingkat II dan Perkembangannya, Mandar Maju, Bandung, 1991.

Pengaturan

Koordinasi Pemerintahan di Daerah. PT. Citra Aditya Bakti, Bandung, 1993.

B. de Goede, Beeld van Het Nederlands Bestuursrecht, Vuga Uitgeverij, B.V. 'SGravenhage, 1986.

Bagir Manan, Beberapa Hal di Sekitar Otonomi Daerah Sebagai Sistem Penyelenggaraan Pemerintahan, Najalah Padjadjaran, Jilid V No.3, Juli-Oktober 1974, Bina Cipta, Bandung, 1974.

Bayu Suryaningrat, Desentralisasi dan Dekonsentrasi Pemerintahan Indonesia - Suatu Analisa (Jilid I), Dewaruci Press, Jakarta, 1981.

Indroharto, UsahaMemahami Peradilan Tata Usaha
Negara - Buku I, Pustaka Sinar Harapan, Jakarta, 1994.

Irawan Soejito, Hubungan Pemerintah Pusat dan Daerah, Bina Aksara, Jakarta, 1981.

Joeniarto, Perkembangan Pemerintah Lokal, Bumi Aksara, Jakarta, 1992.

Josef Riwu Kaho, Prospek Otonomi Daerah di Negara Republik Indonesia, Rajawali Pers, Jakarta, 1988.

Analisa Hubungan Pemerintahan Pusat dan Daerah di Indonesia, Bina Aksara, Jakarta, 1982.

Mariun, Azas-azas Ilmu Pemerintahan, FISIP UGM, Yogyakarta, 1975.

Milton J. Esman, Management Dimension of Development Perspectives and Strategies, Kumarian Press, 1991.

NE. Algra, H.R.W. Gokkel, Saleh Adiwinata, H. Boerhanuddin St. Batoeah, Kamus Istilah Hukum-Fockema Adreae Belanda Indonesia, Binacipta, Bandung, 1983.

Soewoto, Kekuasaan dan Tanggung Jawab Presiden Selaku Mandataris MPR, Yuridika-Majalah FH.UNAIR No. 5 Tahun II, Agustus - September, 1987.

The Liang Gie, Pertumbuhan Pemerintahan Daerah di Negara Republik Indonesia, Jilid III, Gunung Agung, Jakarta, 1968 . 